\title{
Retinoschisis
}

\section{Its significance and management}

\author{
A. R. ELKINGTON AND J. J. KANSKI \\ Moorfields Eye Hospital, High Holborn Branch, London, W.C.I.
}

Retinoschisis is a splitting of the neural elements of the retina which generally occurs first in the outer plexiform layer. Two types are described: the rare congenital sex-linked type affecting males, and the more common acquired or "senile"type which may occur in adults of any age and even in children. In this paper only the latter type will be considered.

Although acquired retinoschisis is common, there is still disagreement on how the condition is best treated. Some advocate a conservative approach, because in their experience it is a benign, non-progressive condition which may even regress spontaneously, and they argue that surgical intervention does not improve the visual prognosis. Others recommend prophylaxis to forestall spread to the macula or the development of a true detachment.

The purpose of this survey was to determine whether any specific features might assist the surgeon in predicting the course of the condition in any given patient so as to avoid unnecessary surgery.

\section{Patients and methods}

All the patients surveyed showed the features of acquired (senile) retinoschisis as described by Shea, Schepens, and von Pirquet (1960). They attended the Retina Unit of the High Holborn Branch of Moorfields between 1959 and July, 1972. Of the 86 patients examined, 48 were males and $3^{8}$ females. One patient had lost an eye, leaving $\mathrm{I} 7 \mathrm{I}$ eyes in the survey; retinoschisis was present in Ioo eyes. A few patients were seen on one occasion only for a second opinion.

Each patient was studied by both the direct and indirect ophthalmoscope, using scleral depression and the Goldmann three-mirror contact lens when indicated, and the visual fields were plotted. Any symptoms were recorded and particular note was taken of the following features:

(I) Site and extent of retinoschisis

(3) Pseudo-dialyses

(2) Refraction

(4) High-water marks.

The hundred patients were classified in two groups (Table I) according to the findings on follow-up.

Table I Follow-up of 100 eyes with retinoschisis

\begin{tabular}{|c|c|c|c|}
\hline $\begin{array}{l}\text { No clinical progression } \\
\text { Spontaneous collapse }\end{array}$ & $\left.\begin{array}{r}74 \\
4\end{array}\right\}$ & Group A & (67 patients) \\
\hline Intervention & 22 & Group B & (I9 patients) \\
\hline
\end{tabular}

Table II shows that there was no difference in the distribution of sex or age between the two groups.

Table II Sex and age at presentation of patients in Group $A$ and Group $B$

\begin{tabular}{|c|c|c|c|c|c|c|c|c|c|}
\hline Age group & $10-20$ & $21-30$ & $3^{I-40}$ & $4^{1-50}$ & $5^{1-60}$ & $61-70$ & $71-80$ & Total & \\
\hline Sex & $M F$ & $M F$ & $M F$ & $M F$ & $M F$ & $M F$ & $M F$ & $M F$ & Total \\
\hline Group A & $1-$ & 21 & 23 & 910 & I 4 I I & 85 & $I-$ & 3730 & 67 \\
\hline Group B & I I & 22 & I - & 24 & 31 & $1-$ & I - & I 8 & I 9 \\
\hline
\end{tabular}


The fact that uncomplicated retinoschisis rarely causes symptoms directly referable to the condition is made clear in Table III.

Table III Reason for presentation of the 67 patients in Group $A$

I. Chance finding at refraction 21

2. Chance finding in hospital 25

3. Field defect noted

4. Floaters

5. Flashes

Total

$\begin{array}{r}4 \\ 16 \\ 1 \\ \hline 67\end{array}$

The refraction, where known, is shown in Table IV, where it is compared with figures for the general population and those found by Shea and others (1960). Few of the patients in Group BN were hypermetropes, but a high percentage were myopes.

Table IV Refraction (per cent.) recorded by previous workers and in present series (no. of eye? in brackets)

\begin{tabular}{|c|c|c|c|c|c|}
\hline Refraction & Hypermetropes & Emmetropes & Myopes & $\begin{array}{l}\text { Mixed } \\
\text { astigmatism }\end{array}$ & 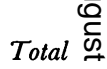 \\
\hline $\begin{array}{c}\text { General population: Jackson (1932) } \\
\text { Harman (1936) }\end{array}$ & $\begin{array}{l}66 \cdot 7 \\
56 \cdot 0\end{array}$ & $\begin{array}{l}13 \cdot 7 \\
14.75\end{array}$ & $\begin{array}{l}19.6 \\
27 \cdot 0\end{array}$ & $2 \cdot 25$ & $\begin{array}{r}1,482 \\
30,006\end{array}$ \\
\hline Retinoschisis: Shea and others (1960) & $57 \cdot 7 \quad(34$ eyes $)$ & $20 \cdot 3 \quad(12)$ & $17 \cdot 0 \quad(10)$ & $5 \cdot 00 \quad(3)$ & \\
\hline $\begin{array}{l}\text { Group A } \\
\text { Group B }\end{array}$ & $\begin{array}{rr}50 \cdot 0 & (22) \\
11 & (2)\end{array}$ & $\begin{array}{rr}27 \cdot 3 & (12) \\
27 \cdot 0 & (5)\end{array}$ & $\begin{array}{ll}23 \cdot 5 & (\text { I } 0) \\
62 \cdot 0 & (\text { I I })\end{array}$ & & \\
\hline
\end{tabular}

Table $\mathrm{V}$ shows the distribution of breaks, demarcation high-water marks, and pseudo-dialyses in the two groups.

Table V Distribution (per cent.) of lesions (no. of eyes in brackets)

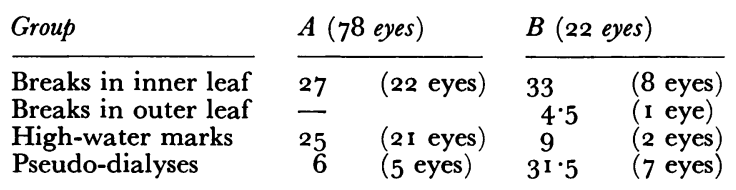

\section{Discussion}

Acquired retinoschisis is an extreme form of microcystoid degeneration (Rutnin and Schepens, 1967) and consequently becomes more common with age; these authors found some degree of schisis in 22 per cent. of those over the age of 40 years. Byer ( 1968$)_{b}^{\omega}$ examined I,500 asymptomatic patients and found schisis in 3.7 per cent. of the whole् series, and in 7 per cent. of those over 40. There may be some doubt as to the exac厉 frequency of the condition, but these studies certainly show that it is common.

Shea and others (1960) emphasized that retinoschisis was not benign in a report of 107 such patients; 29 ( 16 per cent.) of the 178 eyes developed retinal detachment. Okun and Gibis ( 1964 ) reported that retinal detachment developed in 25 of 85 eyes with retinoschisis $\frac{O}{\mathbb{D}}$ and concluded that some form of treatment became necessary in about 25 per cent. ing 
those patients whom they initially elected to cbserve. It is impossible to give exact figures for the frequency of complications in this series because some patients were referred after a retinal detachment had already developed and others with uncomplicated retinoschisis were seen only once. But the fact that 22 of the roo eyes with retinoschisis required surgery agrees with the suggested complication rate of $I$ in 4 .

To avoid spread of the schisis, Pischel (I965) advocated obliteration of the affected area by photocoagulation, whilst Guerry and Bullington (1965) felt it safe merely to seal off the area by the same means. Cryopexy was found by Dobbie (rg69) to eliminate areas of schisis, but the follow-up of his reported cases was inadequate. Gibis (1965) stressed the slow progression of the condition and adopted a conservative approach, unless visual function was threatened, when he attempted to arrest the spread of the schisis by photocoagulation. Shea and others (1960) found that surgery failed to flatten an area of schisis permanently and were loath to try prophylaxis. It was because advice was so conflicting that we tried to discover which patients are at particular risk.

Shea and others (1960) found no relationship between the refractive error and the presence of retinoschisis. Table IV shows that the refractive error of Group A corresponded closely with that of the general population, as recorded by both Jackson (1 932) and Harman (1936), and also with the figures for retinoschisis given by Shea and others (1960). In contrast, Group B comprised 62 per cent. myopes and only I I per cent. hypermetropes. There was no significant difference in the sex and age of the patients in the two groups, as shown in Table II.

Table V illustrates that only 9 per cent. of the patients in Group B had high-water marks, whereas pseudodialyses were more common. Breaks in the inner leaf were equally distributed, and the patient who had breaks in both leaves inevitably developed a retinal detachment.

It can be concluded that the patients at special risk are myopes, and that the presence of a pseudodialysis and the absence of high-water marks should also arouse the surgeon's suspicions of impending complications. In patients who exhibit none of the characteristics described above, an annual examination should usually suffice as complications are unlikely.

\section{Summary}

I oo eyes of 86 patients with acquired (senile) retinoschisis were studied in an attempt to determine whether there were any clinical features which might help the surgeon in predicting the outcome. Complications occurred most frequently in myopic patients with pseudodialyses and no high-water marks.

It is a pleasure to thank Mr. James Hudson for allowing us to study patients under his care.

\section{References}

BYER, N. E. (1968) Arch. Ophthal. (Chicago), 79, 36

CIBIS, P. A. (1965) Trans. Amer. ophthal. Soc., 63, 41 7

DOBBiE, J. G. (1969) Trans. Amer. Acad. Ophthal. Otolaryng., 73, 1047

GUERRY, D., and BUllington, w. (1965) Sth. med. F. (Bgham, Ala.), 58, 862

haRman, N. B. (1936) Brit. med. F., 2, Suppl., p. 214

Jackson, e. (1932) 7. Amer. med. Ass., 98, 132

OKUn, E., and ciBIS, P. A. (1964) Arch. Ophthal. (Chicago), 72, 309

PISGHEL, D. K. (1965) Trans. ophthal. Soc. U.K., 85, 67

RUtnin, U., and SChepens, c. L. (1967) Amer. F. Ophthal., 64, io40

SHEA, M., SCHEPENS, c. L., and von PIRQUeT, s. R. (1960) A.M.A. Arch. Ophthal., 63, 1 